\title{
The Impact of the Morphological Alternation of Subject Markers on Tense/Aspect: The Case of Swahili
}

\author{
Ahmadi Kipacha \\ The Open University of Tanzania
}

Subject markers for the first, second and third person singular in Southern Swahili dialects display morphological variation in that specific forms are chosen with different tense-aspect markers. This paper documents this variation in the different dialects and presents a distributional chart which reveals the symmetric patterns between these subject markers and their corresponding tense-aspect formatives. The study corroborates earlier work in the manifestation of variant morphological tense-aspect formatives of the regional dialects of Swahili by Mazrui (1983).

\section{Introduction}

Affirmative finite verbs in the Swahili Southern Dialects (SD), which include the dialects of Pemba, Tumbatu, Vumba, Makunduchi, Nungwi, Ngome, Mtang'ata and (partly) Unguja, have been observed to display two to three different paradigmatic representations for $1^{\text {st }}$ person singular $(1 \mathrm{sg}), 2^{\text {nd }}$ person singular $(2 \mathrm{sg})$ and $3^{\text {rd }}$ person singular $(3 \mathrm{sg})$ or Class 1 subject markers. The relevant subject markers in SD generally appear as follow:

(1) Singular

$\begin{array}{ll}1^{\text {st }} & n i-, s i^{-} \\ 2^{\text {nd }} & u-, k u^{-} \\ \text {cl.1 } & y u-, a-, k a-\end{array}$

Plural

tu- 'we'

mu- 'you'

wa- 'they'

As can be seen in (1), there are variant sets of the subject agreement marker of $1 \mathrm{sg}, 2 \mathrm{sg}$ and class 1 . The distribution of alternating forms in the $1^{\text {st }}$ person as well as the form $/ y u$-/ for class 1 is limited to few dialects, and hence we will exclude them in the present analysis. The main concern of the paper will be the alternations $u$ - $/ k u$ - and $a-/ k a-$, which have so far received little attention of descriptive Swahilists. There are two reasons why we need to further explore in depth the case of the variant forms $u-/ k u-(2 \mathrm{sg})$ and $a-/ k a-(3 \mathrm{sg})$ : First, the set $u$ -

1 This alternation is confined in Mtang'ata and Vumba dialects in SD (see Temu 1980: 22 and Nurse and Hinnebusch 1993: 400-1). 
/a- (henceforth Set A) is often reported to be in a morphological complementary distribution to the set $k u-/ k a$ - (henceforth Set B) (see Maganga 1990: 161, Nurse and Hinnebusch 1993: 365). Secondly, the relation between subject and tenseaspect (TA) formatives has been drawn from a survey of only few SD members. Now that more monographic studies of SD are available, an attempt is made here to collect samples from numerous SD members to account for the relationship between subject and TA formatives. It is hoped that such a systematic survey will provide a clearer representation of the facts, on which then generalizations and analyses might be based. Data for this study (see appendices Table 1-7) have been collected from the following SD members: Pemba, Tumbatu, Vumba, Makunduchi, Nungwi, Ngome, Mtang'ata and Unguja. Interestingly, no single Northern Swahili dialect (ND) as spoken along the Kenyan and Southern Somali coastline exhibits such myriad shapes of subject or TA formatives (except the ile-/ndo- formatives as noted by Mazrui (1983: 18-20)).

The organization of the paper is as follows: In section 2, I present the distribution of the grammatical alternation of $2 \mathrm{sg}$ and $3 \mathrm{sg}$ subject markers in previous works. In section 3, I present the distribution of variant affirmative TA formatives in SD. In section 4, I present the matrix showing the co-occurrence of $2 \mathrm{sg} / 3 \mathrm{sg}$ subject markers with different TA markers in SD. In section 5, I offer some clues on conditions that govern co-occurrence restrictions of subject markers and their respective TA formatives in SD. In section 6 I present a brief conclusion.

This short descriptive paper does not intend to rely on any specific theoretical underpinnings, however, some terminology and the matrix based approach have been influenced by Carstairs-McCarthy (2001) and Nurse (2003).

\section{The grammatical alternation of $2 \mathrm{sg}$ and $3 \mathrm{sg}$ person subject markers in SD}

Previous analyses of Set A and Set B in Southern Swahili dialects appear intermittently in works of Nurse (1982, 1984/85), Maganga (1990), Nurse and Hinnebusch (1993) and Riedel (2001/2002). It is fair to say that, perhaps, 'a tip of the iceberg' began to appear in Maganga's (1990: 33) analysis of the form $a$ versus $k a$ - in the Unguja dialect : 
(2)
(a) mwalimu a-me-sema
1 teacher 3sg-ANT-say
'The teacher has said'
(b) mwalimu ka- $\varnothing$-sema
1 teacher 3sg-ANT-say
'The teacher has said'

Two opposing paradigmatic verb 'slots' emerge in (2a) and (2b). There is a complementary set of $a$ - and $k a$ - that stand for the $3 \mathrm{sg}$, along with me-versus $\varnothing$ that expresses anteriority. Maganga explains that the choice between $a$ - and $k a-$ is determined by the morphosyntactic category of the perfective aspect (anterior) $m e$-. The $k a$ - shape is chosen whenever overt me- is dropped, otherwise in normal circumstance, we should expect a default $a$ - to be followed by me-.

However, he (ibid: 108) admits that the $k a$ - marker which contrasts with $a$ - has a very restrictive usage in Pemba, but a wider application in Tumbatu and Makunduchi. Furthermore, the shape of anterior marker in Pemba is $n a$ - instead of me-. We can observe here that when dealing with subject person variation in $\mathrm{SD}$, we do not only have to consider the opposition between Set A and Set B subject markers, but also the difference between variant TA formatives, such as $m e$ - and $n a$ - that may express the same semantic meaning. Riedel (2001/2002:13) in her study of the tense and aspect system of the Northern Unguja Kinungwi dialect (akin to Tumbatu) organizes the singular animate markers into Set A and Set B as follows:

\begin{tabular}{llll}
\multicolumn{2}{c}{ Set A } & Set B & \\
$1^{\text {st }}$ & $n i-$ & $n i-$ & 'I' \\
$2^{\text {nd }}$ & $u-$ & $k u-$ & 'you' \\
$3^{\text {rd }}$ & $a-$ & $k a-$ & 's/he'
\end{tabular}

In fact, what Riedel demarcates for Nungwi in (3) is somewhat similar to the analyses of Lambert (1953: 15) for Vumba and Nurse (1982:175) for SD respectively. Riedel (ibid.) explains that Set B in Nungwi is used primarily in the past, anterior, future, completive and progressive, while Set A is used primarily in the conditional, subjunctive and in relatives. Maganga (1990: 2289) makes a similar observation for Makunduchi in which he analyses Set A as mainly found in the subjunctive, the negative, conditional and situative.

Nurse and Hinnebusch (1993: 365-6) also note that Set B, as derived from Common Bantu/Proto Sabaki $* k u-/ * k a-$, co-occurs with certain positive tense/aspects in Pokomo, SD, Mwani and Comorian. 
The proposal by Mazrui (1983: 20) to account for variation in aspect marking in the four major Swahili dialects of Mvita, Bajuni, Amu and Unguja only mentions $m e-/ k a$ - and ile/ndo as variant TA formatives. Within his sample, the variation $m e-/ k a$ - appears only in Unguja (as indeed in SD). However, Mazrui did not reach a conclusion whether the alternation between me- and $\mathrm{ka}$ is free or is contextually bound, and he appeals for more empirical investigation of the matter. However, to obtain data to adequately demonstrate the 'complementary distribution' between sets of 2sg and 3sg subject formatives versus variant TA markers is not an easy task. Examples of Set A and Set B subject markers found in SD are scattered in different sources, and are collated and reorganized in the form of distributional charts. As variation in subject formatives is sensitive to variation in TA formatives, I present first the distribution of the variant TA formatives in SD.

\section{The distribution of variant TA formatives in SD}

It should be borne in mind that TA formatives among SD members are not entirely homogeneous. The following table presents a summary of the situation:

(4) Variant TA formatives (affirmative) in SD

\begin{tabular}{|c|c|c|c|c|c|c|c|c|}
\hline & Mak & $\mathrm{Tu}$ & $\mathrm{Pe}$ & $\mathrm{Vu}$ & Ngw & Mt & $\mathrm{Ng}$ & Ung \\
\hline $\begin{array}{l}\text { na-, a-, hu- } \\
\text { (Present) }\end{array}$ & na- & $\begin{array}{l}\mathrm{na}-, \mathrm{a}-/ \\
\mathrm{hu}-\end{array}$ & a- & & na-, a- & a- & na(ku)-, a- & na-, a- \\
\hline $\begin{array}{l}\text { na-, a- } \\
\text { me-, ma- } \\
\varnothing . .(\text { VC) } \\
\text { (Anterior) }\end{array}$ & $\begin{array}{l}\text { me- } \\
\varnothing . .(\mathrm{VC})\end{array}$ & $\begin{array}{l}\text { ma- } \\
\varnothing . .(\mathrm{VC})\end{array}$ & $\begin{array}{l}\text { na- } \\
\varnothing . .(\mathrm{VC})\end{array}$ & $\begin{array}{l}\text { na-, a- } \\
\varnothing . .(\mathrm{VC})\end{array}$ & $\begin{array}{l}\text { ma- } \\
\varnothing . .(\mathrm{VC})\end{array}$ & $\begin{array}{l}\text { na- } \\
\text { me- } \\
\varnothing . .(\mathrm{VC})\end{array}$ & $\varnothing . .(\mathrm{VC})$ & $\begin{array}{l}\text { me- } \\
\varnothing ?\end{array}$ \\
\hline $\begin{array}{l}\text { (me)sha-, ma- } \\
\text { (Completive) }\end{array}$ & (me)sa- & sha- & & sha- & sha- & sha- & sha- & (me)sha- \\
\hline \begin{tabular}{|l} 
li-/e-/, \\
$\varnothing . .($ VC) \\
(Past)
\end{tabular} & $\begin{array}{l}\text { li- } \\
\varnothing . .(\mathrm{VC})\end{array}$ & $\begin{array}{l}\text { li, } \\
\varnothing . .(\mathrm{VC})\end{array}$ & $\begin{array}{l}\text { e-, } \\
\varnothing . .(\mathrm{VC})\end{array}$ & li- & \begin{tabular}{|l} 
li? \\
\end{tabular} & & $\begin{array}{l}\text { ri-, } \\
\varnothing . .(\mathrm{VC})\end{array}$ & li- \\
\hline \begin{tabular}{|l|} 
ta-, cha- \\
nda- \\
(Future)
\end{tabular} & cha- & ta- & ta- & cha- & $\begin{array}{l}\text { ta- } \\
\text { nda- }\end{array}$ & ta- & ta- & ta- \\
\hline \begin{tabular}{|l|} 
nga-, nge- \\
(Conditional)
\end{tabular} & nge- & nge- & nga- & nga- & nge- & nga- & nga- & nge- \\
\hline $\begin{array}{l}\text { ki-, ka- } \\
\text { (Situative) }\end{array}$ & ka- & ka- & ki- & ka- & ki- & ka- & ki- & ki- \\
\hline
\end{tabular}

Key: $\mathrm{Mak}=$ Makunduchi; $\mathrm{Tu}=$ Tumbatu; $\mathrm{Ngw}=$ Nungwi; $\mathrm{Pe}=$ Pemba; $\mathrm{Vu}=$ Vumba; Mt= Mtang'ata; $\mathrm{Ng}=$ Ngome, Ung= Unguja

Note that all TA formatives have variant shapes in SD. With the exception of the future markers $t a-/ c h a-$, whose variation is phonological, all variants forms are morphologoical, rather than phonologically motivated. Some alternations, such 
as $n g e-/ n g a-, m e-/ m a-$ and $k i-/ k a-$ represent different stages of grammaticalization.

We evidently see anterior with various morphological formatives such as $n a-, a-/ m e-, m a-/ \varnothing . .(V C)$. We shall see later how they interact with the choice of subject formatives. Clearly noticeable alternations are rare cases of TA formatives for future tense $n d a-/ t a-/ c h a-$.

We also see in for the expression of past tense the occurrence of the alternation $l i$-/e- against $\varnothing$..(VC). Several gaps may be interpreted as lack of recorded data or suspicious occurrence of form (e.g. loans). Our data also provide us with clear evidence that in all SD members, as well as in Standard Swahili, there is no anterior (perfective) alternation between the formatives -ile/ndo- as found the Northern Swahili dialects of Mvita, Amu and Bajuni (see Mazrui 1983: 18). The data also indicate that Mazrui (1983: 20) has wrongly interpreted 3sg $\mathrm{ka}$ - as a perfective maker (in cases like Juma ka- $\varnothing$-fika 'Juma has arrived') alternating with $m e$ - formatives in Unguja. Rather, $k a$ - functions as a 3sg marker in Unguja as well as in SD in general.

\section{The co-occurrence of $2 / 3 \mathrm{sg}$ subject marker with TA markers in SD}

I present the distributional chart of Set A and Set B subject markers against TA formatives based on data that represent examples from seven SD members (see Tables 1-7 in the Appendix which present a fuller picture). 
(5) Co-occurrence of $2 / 3 \mathrm{sg}$ subject markers with TA markers in SD

\begin{tabular}{|c|c|c|c|c|c|c|c|c|c|c|c|c|c|c|}
\hline & \multicolumn{2}{|c|}{ Mak } & \multicolumn{2}{|c|}{$\mathrm{Tu}$} & \multicolumn{2}{|c|}{$\mathrm{Pe}$} & \multicolumn{2}{|c|}{$\mathrm{Vu}$} & \multicolumn{2}{|c|}{ Ngw } & \multicolumn{2}{|c|}{$\mathrm{Mt}$} & \multicolumn{2}{|c|}{$\mathrm{Ng}$} \\
\hline SET & A & B & A & B & A & B & A & B & A & B & A & B & A & B \\
\hline $\begin{array}{l}\text { na-, a- } \\
\text { (PRES) }\end{array}$ & $\sqrt{ }$ & $\sqrt{ }$ & $\sqrt{ }$ & $\sqrt{ }$ & $\sqrt{ }$ & & & & & $\sqrt{ }$ & $\sqrt{ }$ & & $\sqrt{ }$ & \\
\hline $\begin{array}{l}\text { na- } \\
\text { a- } \\
\text { me-, ma- } \\
\varnothing . .(\text { VC) } \\
\text { (ANT) }\end{array}$ & & $\begin{array}{l}\sqrt{ } \\
\sqrt{ }\end{array}$ & & $\sqrt{ }$ & & $\sqrt{ }$ & & $\begin{array}{l}\sqrt{ } \\
\sqrt{ } \\
\sqrt{ }\end{array}$ & & $\begin{array}{l}\sqrt{ } \\
?\end{array}$ & & $\begin{array}{l}\sqrt{ } \\
\sqrt{ }\end{array}$ & & $\sqrt{ }$ \\
\hline $\begin{array}{l}\text { (me)sha- } \\
\text { ma- } \\
(\mathrm{COMP})\end{array}$ & $\sqrt{ }$ & $\sqrt{ }$ & $\sqrt{ }$ & $\begin{array}{l}\sqrt{ } \\
\sqrt{ }\end{array}$ & & & & $\sqrt{ }$ & $\sqrt{ }$ & $\sqrt{ }$ & & $\sqrt{ }$ & $\sqrt{ }$ & $\sqrt{ }$ \\
\hline $\begin{array}{l}\text { li-, e- } \\
\varnothing . .(\mathrm{VC}) \\
(\mathrm{PST})\end{array}$ & $\sqrt{ }$ & $\sqrt{ }$ & $\sqrt{ }$ & $\sqrt{ }$ & $\sqrt{ }$ & $\sqrt{ }$ & $\sqrt{ }$ & & & & & & $\sqrt{ }$ & $\sqrt{ }$ \\
\hline $\begin{array}{l}\text { ta-, cha- } \\
\text { nda } \\
(\mathrm{FUT})\end{array}$ & $\sqrt{ }$ & $\sqrt{ }$ & $\sqrt{ }$ & & $\sqrt{ }$ & & $\sqrt{ }$ & & $\sqrt{ }$ & $\begin{array}{l}\sqrt{ } \\
\sqrt{ }\end{array}$ & $\sqrt{ }$ & & $\sqrt{ }$ & \\
\hline $\begin{array}{l}\text { nga ,nge- } \\
\text { (COND) }\end{array}$ & $\sqrt{ }$ & & $\sqrt{ }$ & & $\sqrt{ }$ & & $\sqrt{ }$ & & $\sqrt{ }$ & & $\sqrt{ }$ & & $\sqrt{ }$ & \\
\hline $\begin{array}{l}\text { ki-, ka- } \\
\text { (SIT) }\end{array}$ & $\sqrt{ }$ & & $\sqrt{ }$ & & $\sqrt{ }$ & & $\sqrt{ }$ & & $\sqrt{ }$ & & $\sqrt{ }$ & & $\sqrt{ }$ & \\
\hline
\end{tabular}

key: $\sqrt{ }$ 'present'; gap= absent or not found

For typographical convenience, Unguja data is excluded from the chart although it has 3sg $k a$ - representing 'marked' Set B. The Unguja anterior form $\varnothing$...(VC) occurs with this $3 \mathrm{sg} \mathrm{ka}$-formative. Set $\mathrm{A}$ is used in the conditional and the situative, and it appears in almost all future cases. But only Nungwi and Makunduchi have both Set A and B followed by a future marker. Completive is free to choose both Set A and Set B. The anterior/past in the form of $\varnothing$...(VC) selects always Set B subject markers.

There is no redundancy in the of shape $n a$ - as anterior/present in Makunduchi, Tumbatu, Nungwi and Ngome on the one hand, and Pemba, Vumba and Mtang'ata on the other. This is an example of 'substitution' of the $n a$-shape. If $n a$ - is chosen as anterior then it will not appear as present/progressive and vice versa. Interestingly, $n a$ - as anterior occurs exclusively with Set B. This is an area we can confidently talk of 'mutual exclusiveness'. There are 'rare' cases such as $a$ - present in Tumbatu and $m a$ anterior in Nungwi that are reported to co-occur exclusively with Set B. This may be regarded as isolated cases pending further cross-linguistic data.

Exclusivity strictly applies when Set A is chosen in the conditional, and situative. Set B is exclusively used when $\varnothing$..(VC) appears in anterior/past. 


\section{Discussion}

The following are my proposals based on the general properties of cooccurrence restrictions between TA and subject marker sets in (5) above.

There are three scenarios in (5) that characterize the selection of sets in SD finite verbs: Firstly, TA formatives such as $n a$ - (present), cha- (future) and mesha- (completive) in Makunduchi, na- (present) in Tumbatu and sha(completive) in Nungwi and Ngome may agree with both Set A and Set B. These can be regarded as free forms and they are not bound by any particular subject formatives.

Secondly, TA formatives such as $\varnothing$..(VC) that stand for anterior/past tend to select Set B only. Others that also appear exclusively with Set B are $m a$ (completive) and $m e$ - (anterior) in Tumbatu, $n d a$ - (future) and $m e$ - (anterior) in Nungwi, and $n a-$ (anterior) in Pemba, Vumba and Mtangata. These are clear cases of exclusivity.

Thirdly, the last scenario is marked by the exclusive selection of Set A in $n g e-, n g a-$ (conditional), $k i-/ k a-$ (situative), and $l i-, e-$ (past). It is an open question whether any of these scenarios is in some sense more basic or unmarked than the others. I will not attempt to answer this question here, but it might help to address this question by separating the TA formatives involved in the alternations into those which occur with Set A and those which occur with Set B. In the following table, TA markers which occur with subject markers of Set $A$ are found in the top row, while those occurring with subject markers of Set B are found in the bottom row:

\begin{tabular}{|l|l|l|l|l|l|l|l|}
\hline & present & past & anterior & completive & future & conditional & situative \\
\hline Cell A & na-, a- & li-, e- & me-, ma- & (me)sha- & $\begin{array}{l}\text { ta-, } \\
\text { cha- }\end{array}$ & nge-, nga- & ki-, ka- \\
\hline Cell B & na-, a & $\varnothing . .($ VC) & $\begin{array}{l}\text { na-, a-, } \\
\varnothing . .(V C)\end{array}$ & -sha, ma- & nda-, ta & & \\
\hline
\end{tabular}

TA markers in the top row, occurring with Set A subject markers, includes TA markers which cut across the whole of Swahili spectrum and Sabaki in general. In contrast, TA markers occurring with Set B subject markers, are limited to SD, and other peripheral Sabaki members such as Comoro, Pokomo (Nurse p.c.) and Mwani. By virtue of being less common within Swahili dialects, these markers might be called 'marked TA' or constituting a 'subparadigm'.

Why should the TA markers which occur with Set B subject markers be limited to SD and other peripheral Sabaki members only? The answer is not 
clear-cut. One possibility seems to be that two or three variant paradigm structures may be present in the grammatical system of these dialects, as speakers may well have borrowed a grammatical structure of the neighbouring dialects or languages.
(7)
(a) a-ri-rim-a
3sg-PAST-cultivate-FV
'S/he cultivated'
(b) ka- $\varnothing$-rim-a
3sg-PAST-cultivate-FV
'S/he cultivated'

To many coastal Standard Swahili speakers, the choice of $a$ - $/ r i$ - versus $k a-/ \varnothing$ - is not strange. These are two paradigmatic structures representing the expression 'S/he cultivated'. The format ( $7 b$ ) is disappearing fast in formal settings. This implies that over time it will cease to exist and thus the language will remain with only one format which we can regard as the general format. We have no evidence of crisscrossing of forms from one paradigm to another.

\section{Conclusion}

Illustration of co-occurrence restrictions of SM over TA formatives in the affirmative finite verbs from SD is clear evidence that more research is to be done to uncover the hidden phenomenon of morphologically conditioned allomorphy in Bantu. In addition to the questions raised here, further research is needed to ascertain whether subject markers are selected on the basis of TA markers, or whether, contrarily, specific TA markers are selected on the basis of subject markers. This short article has only raised these questions, but at least I hope it has pinpointed areas for further scrutiny.

\section{$7 \quad$ References}

Carstairs-McCarthy, A. 2001. Grammatically conditioned allomorphy, paradigmatic structure, and the ancestry constraint. Transactions of the Philological Society 99: 211-245.

Chum, H. 1994. Msamiati wa pekee wa KiKae Kae Specific Vocabulary. Uppsala: Nordic Association of African Studies.

Lambert, H. E. 1953. The Vumba Verb. Swahili 23: 14-33.

Maganga, C. 1990. A study of the Morphophonology of Standard Swahili, Kipemba, Kitumbatu and Kimakunduchi. Unpublished Ph.D. University of Dar es Salaam.

Mazrui, A. 1983. Aspect marking in Swahili: accounting for variation. Swahili 50/2: 18-26. 
Nurse, D. 1982. A tentative classification of the primary dialects of Swahili. SUGIA 4: 165205.

Nurse, D. 1984/85. A historical view of the southern dialects of Swahili. SUGIA 6: 225-50.

Nurse, D. and T. Hinnebusch. 1993. The Swahili and Sabaki: A Linguistic History. Berkeley, Cal.: University of California Press.

Nurse, D. 2003. Tense and Aspect in Chaga. APAL 1: 69-90.

Riedel, K. 2001/2002. The Tense-Aspect system of KiNungwi, Ms, Department of the Languages and Cultures of Africa. SOAS.

Sengo, T. 1995. Itikadi katika jamii za Kiswahili in Mlacha, S. and A. Hurskainen (eds.) Lugha, Utamaduni na Fasihi Simulizi ya Kiswahili, TUKI: 27-44.

Shihhabudi, S and M. Mnyampala. 1977. Historia ya Kiswahili. Nairobi: Oxford University Press.

Temu, C. 1980. Lahajaza Kiswahili. TUKI (mimeo).

Whiteley, W. 1956. Kimtnga'ata A Dialect of the Mrima Coast. Studies in Swahili Dialect 1. Kampala.

Whiteley, W. 1958. The Dialects and Verse of Pemba. Studies in Swahili Dialect, 4. Kampala.

Whiteley, W. 1959. An introduction to the Rural Dialects of Zanzibar, Part 1. Swahili 30: 4169. 


\section{Appendices}

Table 1: Makunduchi

\begin{tabular}{|c|c|c|}
\hline TA & SET A & SET B \\
\hline $\begin{array}{l}\text { /na-/ } \\
\text { 'Present' }\end{array}$ & $\begin{array}{l}\text { (a) chukua u-na-cho-chak-a } \\
\text { take 2sg-PRS-REL-want-FV } \\
\text { 'Take anything you want' } \\
\text { (Whiteley 1959: 64) }\end{array}$ & $\begin{array}{l}\text { (a) Ama ku-na-kuf-a fwa! } \\
\text { if 2sg-PROG-die-FV die } \\
\text { 'If you are dying die' } \\
\text { (Chum 1995: 10) } \\
\text { (b) ka-na-ngi-a } \\
\text { 3sg-PROG-enter-FV } \\
\text { 'S/he is entering' } \\
\text { (Sengo 1995: 32) } \\
\end{array}$ \\
\hline $\begin{array}{l}\text { /me-, ma-, } \\
\varnothing \ldots(\mathrm{VC}) / \\
\text { 'Anterior' }\end{array}$ & & $\begin{array}{l}\text { (a) } k u \text {-me-imb- } a \\
\text { 2sg-ANT-sing-FV } \\
\text { 'You have sung' } \\
\text { (Maganga 1990: 228-9) } \\
\text { (b) ke-me-law-a } \\
\text { 3sg-ANT-come-FV } \\
\text { 'S/he has come' } \\
\text { (Chum 1995: 11) } \\
\text { (c) ku- } \varnothing \text {-und-u } \\
\text { 2sg-ANT-make-VC } \\
\text { 'You have made' } \\
\text { (Whiteley 1959: 65) } \\
\end{array}$ \\
\hline $\begin{array}{l}\text { /(me)sha-, ma-/ } \\
\text { 'Completive' }\end{array}$ & & $\begin{array}{l}\text { (a) ke-mesa-i-bwes-a } \\
\text { 3sg-COMP-OM-torn-FV } \\
\text { 'S/he has torn it' } \\
\text { (Chum 1995: 10) } \\
\text { (b) ku-she-choge-a kulya? } \\
\text { 2sg-COMP-push_over-FV here } \\
\text { 'Have you finished pushing over } \\
\text { here' (Whiteley 1959: 59) }\end{array}$ \\
\hline $\begin{array}{l}\text { /li-, e-, } \varnothing \ldots(\mathrm{VC}) / \\
\text { 'Past' }\end{array}$ & $\begin{array}{l}\text { (a) } a-\varnothing-v y o-k w i s-a \\
\text { 3sg-PST-REL-finish-FV } \\
\text { 'When he finished' } \\
\text { (Whiteley 1959: 204) }\end{array}$ & $\begin{array}{l}\text { (a) } k u-\varnothing \text {-sumk- } a \\
\text { 3sg-PST-sell-FV } \\
\text { 'You ran' } \\
\text { (Maganga 1990: 228-9) } \\
\text { (b) } k a-\varnothing-u z-a \\
\text { 3sg-PST-sell-FV } \\
\text { 'S/he sold' } \\
\text { (Maganga 1990: 228-9) }\end{array}$ \\
\hline $\begin{array}{l}\text { / cha-, nda-/ } \\
\text { 'Future' }\end{array}$ & & $\begin{array}{l}\text { (a) } k a-c h a-v a t-a \\
\text { 3sg-FUT-get-FV } \\
\text { 'S/he will get' } \\
\text { (Maganga 1990: 228-9) }\end{array}$ \\
\hline $\begin{array}{l}\text { /nga-, nge/ } \\
\text { 'Conditional' }\end{array}$ & $\begin{array}{l}\text { (a) } u \text {-nge-m-on- } a \\
\text { 2sg-COND-2OM-see-FV } \\
\text { 'You would have seen' } \\
\text { (Whiteley 1959: 61) }\end{array}$ & \\
\hline $\begin{array}{l}\text { /ki-, ka-/ } \\
\text { 'Situative' }\end{array}$ & $\begin{array}{l}\text { (a) } u \text {-ka-fik-a kuchamona } \\
\text { 2sg-SIT-arrive-FV } \\
\text { 'If you arrive you will find him' } \\
\text { (Whiteley 1959: 60) }\end{array}$ & \\
\hline
\end{tabular}


Table 2: Tumbatu

\begin{tabular}{|c|c|c|}
\hline TA & SET A & SET B \\
\hline $\begin{array}{l}\text { /na-, a-/ } \\
\text { 'Present' }\end{array}$ & & $\begin{array}{l}\text { (a) } k u \text {-na-zi-uz-a? } \\
\text { 2sg-PROG-OM-sell-FV } \\
\text { 'Are you selling it?' } \\
\text { (N \& H 1993: 408) } \\
\text { (a) } k w \text {-a-lamuk-a } \\
\text { 2sg-PRST-wake_up-FV } \\
\text { 'You wake up' } \\
\text { (Maganga 1990: 160) } \\
\end{array}$ \\
\hline $\begin{array}{l}\text { /na-,a-, me-, ma-, } \\
\varnothing \ldots \text {...VC) } \\
\text { 'Anterior' }\end{array}$ & & \\
\hline $\begin{array}{l}\text { /(me)sha-, ma-/ } \\
\text { 'Completive' }\end{array}$ & & $\begin{array}{l}\text { (a) } k u \text {-sha-kwimb-a } \\
\text { 2sg-COMP-sing-FV } \\
\text { 'You have sung' } \\
\text { (Maganga 1990: 155) } \\
\text { (b) } k \text {-sha-kwembilw-a } \\
\text { 3sg-COMP-tell-FV } \\
\text { 'S/he has been told' } \\
\text { (Maganga 1990: 190) }\end{array}$ \\
\hline $\begin{array}{l}\text { /li-, e-, }, \text { Ø...(VC)/ } \\
\text { 'Past' }\end{array}$ & & $\begin{array}{l}\text { (a) } k \text { - } \varnothing \text {-og-o } \\
\text { 2sg-PST-bath-VC } \\
\text { 'You bathed' } \\
\text { (Maganga 1990: 160) } \\
\text { (b) } k w \text { - } \varnothing \text {-ambil-i watu } \\
\text { 3sg-PST-tell-VC } \\
\text { 'S/he told people' } \\
\text { (Maganga 1990: 160) }\end{array}$ \\
\hline \multicolumn{3}{|l|}{$\begin{array}{l}\text { /ta-, ca-, nda-/ } \\
\text { 'Future' }\end{array}$} \\
\hline \multicolumn{3}{|l|}{$\begin{array}{l}\text { /nga-, nge/ } \\
\text { 'Conditional' }\end{array}$} \\
\hline $\begin{array}{l}\text { /ki-, ka-/ } \\
\text { 'Situative' }\end{array}$ & & \\
\hline
\end{tabular}


Table 3: Nungwi

\begin{tabular}{|c|c|c|}
\hline TA & SET A & SET B \\
\hline $\begin{array}{l}\text { /na-/ } \\
\text { 'Present' }\end{array}$ & & $\begin{array}{l}\text { (a) } k u-n a-k w e n d-a \quad k u-m-o n-a \\
\text { 2sg-PROG-go-FV to-OM-see-FV } \\
\text { 'You are going to see him' } \\
\text { (Riedel 2002: 28) }\end{array}$ \\
\hline $\begin{array}{l}\text { /me-, ma-/ } \\
\text { 'Anterior' }\end{array}$ & $\begin{array}{l}\text { (a) } u \text {-ma-jafyagiy-a? } \\
\text { 2sg-ANT-sweep-FV } \\
\text { 'Have you swept?' } \\
\text { (Riedel 2002: 19) }\end{array}$ & $\begin{array}{l}\text { (a) ka-ma-vay-a kanga } \\
\text { 3sg-ANT-dress-FV kanga } \\
\text { 'S/he is wearing a kanga' } \\
\text { (Riedel 2002: 19) }\end{array}$ \\
\hline $\begin{array}{l}/(\mathrm{me}) \text { sha-, ma-/ } \\
\text { 'Completive' }\end{array}$ & $\begin{array}{l}\text { (a) } u \text {-ma-kuly-a? } \\
\text { 2sg-ma-eat-FV } \\
\text { 'Have you eaten?' } \\
\text { (Riedel 2002: } 22 \text { ) }\end{array}$ & $\begin{array}{l}\text { (a) } k u-s h a-k u l y-a \\
\text { 2sg-COMPL-eat-FV } \\
\text { 'Have you eaten?' } \\
\text { (Riedel 2002: } 28 \text { ) }\end{array}$ \\
\hline $\begin{array}{l}/ 1 \mathrm{i}-, \mathrm{e}-, \varnothing \ldots(\mathrm{VC}) / \\
\text { 'Past' }\end{array}$ & $\begin{array}{l}\text { (a) } a-\varnothing-p o-f i k-a \\
\text { 3sg-PST-REL-arrive-FV } \\
\text { 'When s/he arrived' } \\
\text { (Riedel 2002: 17) }\end{array}$ & $\begin{array}{l}\text { (a) } k a-\varnothing-j-a \\
3 \text { sg-PST-come-FV } \\
\text { 'S/he came' } \\
\text { (Riedel 2002: 28) } \\
\text { (b) } k e-\varnothing-n d-e \\
\text { 3sg-PST-go-VC } \\
\text { 'S/he went' } \\
\text { (Riedel 2002: 16) }\end{array}$ \\
\hline $\begin{array}{l}\text { /ta-, ca-, nda-/ } \\
\text { 'Future' }\end{array}$ & 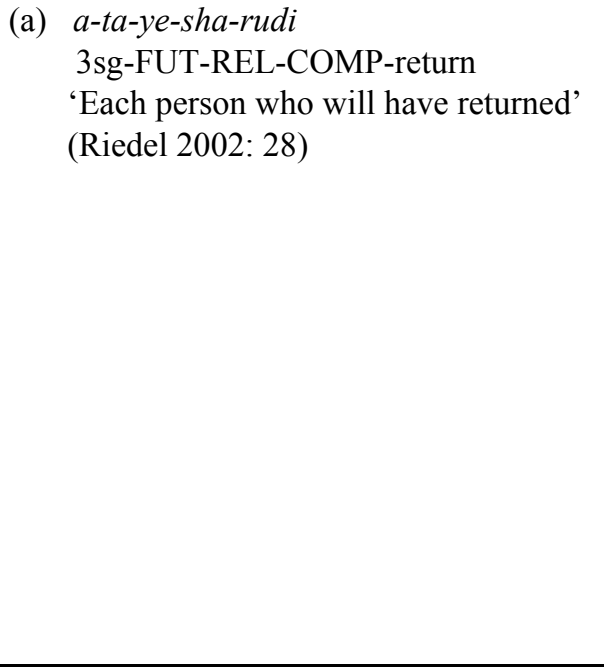 & $\begin{array}{l}\text { (a) ka-ta-ye-ja uka veye } \\
\text { 3sg-FUT-REL-come-FV } \\
\text { 'S/he is the one who will leave' } \\
\text { (Riedel 2002: 27) } \\
\text { (b) ka-ta-som-a } \\
\text { 3sg-FUT-read-FV } \\
\text { 'S/he will read' } \\
\text { (Riedel 2002: 26) } \\
\text { (c) ka-nda-fika } \\
\text { 3sg-FUT-arrive-FV } \\
\text { 'S/he is going to arrive' } \\
\text { (Riedel 2002: 28) } \\
\text { (d) ku-nda-mon-a } \\
\text { 3sg-FUT-see-FV } \\
\text { 'You are going to see him' } \\
\text { (Riedel 2002: } 28 \text { ) }\end{array}$ \\
\hline $\begin{array}{l}\text { /nga(li)-, nge(li)/ } \\
\text { 'Conditional' }\end{array}$ & 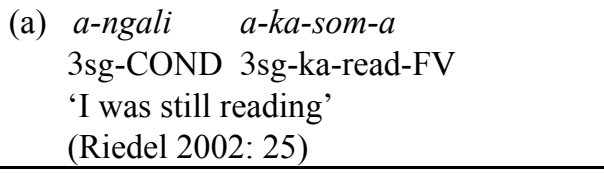 & \\
\hline $\begin{array}{l}\text { /ki-, ka-/ } \\
\text { 'Situative' }\end{array}$ & 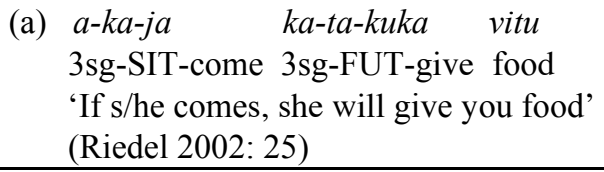 & \\
\hline
\end{tabular}


Table 4: Pemba

\begin{tabular}{|c|c|c|}
\hline TA & SET A & SET B \\
\hline $\begin{array}{l}\text { /na(ku)-, a-/ } \\
\text { 'Simple Present' }\end{array}$ & $\begin{array}{l}\text { (a) } w \text {-a-ank-a } \\
\text { 2sg-PRS-wake_up-FV } \\
\text { 'You wake up' } \\
\text { (Maganga 1990: 112) }\end{array}$ & \\
\hline $\begin{array}{l}\text { /na-/ } \\
\text { 'Anterior' }\end{array}$ & & $\begin{array}{l}\text { (a) } k a-n a-u k-a \\
\text { 3sg-ANT-return-FV } \\
\text { 'S/he has returned' } \\
\text { (N \& H 1993: 420) }\end{array}$ \\
\hline $\begin{array}{l}\text { /(me)sha-, ma-/ } \\
\text { 'Completive' }\end{array}$ & & \\
\hline $\begin{array}{l}\text { /li-, e-, } \varnothing \ldots(\mathrm{VC}) / \\
\text { 'Past' }\end{array}$ & $\begin{array}{l}\text { (a) } w \text {-e-ank-a } \\
\text { 2sg-PST-wake_up-FV } \\
\text { 'You woke up' } \\
\text { Maganga (1990: 112) }\end{array}$ & $\begin{array}{l}\text { (a) } k u-\varnothing-\text { pik-i leo } \\
\text { 2sg-PST-cook-VC today } \\
\text { 'Did you cook today?' } \\
\text { (Whiteley 1959: 15) } \\
\text { (b) } k w \text { - } \varnothing \text {-end-e jana? } \\
\text { 2sg-PST-go-VC } \\
\text { 'Did you go today?' } \\
\text { (Whiteley 1959: } 15 \text { ) } \\
\end{array}$ \\
\hline $\begin{array}{l}\text { /ta-, cha-, nda-/ } \\
\text { 'Future' }\end{array}$ & $\begin{array}{l}\text { (a) } a-t a-k w e n d-a \\
\text { 3sg-FUT-go } \\
\text { 'S/he will go' } \\
\text { (Whiteley 1959: 15) } \\
\end{array}$ & \\
\hline \multicolumn{3}{|l|}{$\begin{array}{l}\text { /nga-, nge/ } \\
\text { 'Conditional' }\end{array}$} \\
\hline $\begin{array}{l}\text { /ki-, ka-/ } \\
\text { 'Situative' }\end{array}$ & & \\
\hline
\end{tabular}


Table 5: Vumba

\begin{tabular}{|c|c|c|}
\hline TA & SET A & SET B \\
\hline $\begin{array}{l}\text { /na-/ } \\
\text { 'Anterior' }\end{array}$ & & $\begin{array}{l}\text { (a) } k u \text {-na-fyom-a } \\
\text { 2sg-ANT-read-FV } \\
\text { 'You have read' } \\
\text { (N \& H 1993: 422) } \\
\text { (b) ka-na-kufw-a } \\
\text { 3sg-ANT-die-FV } \\
\text { 'S/he has died' } \\
\text { (N \& H 1993: 376) }\end{array}$ \\
\hline $\begin{array}{l}\text { /a-/ } \\
\text { 'Immed. Anterior' }\end{array}$ & & $\begin{array}{l}\text { (a) } k w-a-k u b w-a \\
\text { 2sg-Imm.ANT-fall-FV } \\
\text { 'You have just fallen' } \\
\text { (N \& H 1993: 422) } \\
\text { (b) } k(a)-a-f i k-a \\
\text { 3sg-Imm.ANT-arrive-FV } \\
\text { 'S/he has just arrived' } \\
\text { (N \& H 1993: 366) }\end{array}$ \\
\hline $\begin{array}{l}\text { /(me)sha-, ma-/ } \\
\text { 'Completive' }\end{array}$ & & $\begin{array}{l}\text { (a) } k w a-s h a-i n j i k-a \\
\text { 2sg-COMP-write-FV } \\
\text { 'You have written' } \\
\text { (Lambert 1953: 30) } \\
\text { (b) ka-sha-kuj-a } \\
\text { 3sg-COMP-arrive-FV } \\
\text { 'S/he has arrived' } \\
\text { (Lambert 1953: 30) }\end{array}$ \\
\hline $\begin{array}{l}\text { /li-, e-, } \varnothing \ldots(\mathrm{VC}) / \\
\text { 'Past' }\end{array}$ & $\begin{array}{l}\text { (a) } u \text { - } \varnothing \text {-vivi } \\
\text { 2sg-PST-be-how } \\
\text { 'What sort of person are you?' } \\
\text { (Lambert 1953: } 30 \text { ) } \\
\text { (b) } a \text {-li-vo-ondok-a... } \\
\text { 3sg-PST-REL-go-FV } \\
\text { 'As s/he went ...' } \\
\text { (Lambert } 1953: 38 \text { ) }\end{array}$ & $\begin{array}{l}\text { (a) } k a-\varnothing-f u \\
\text { 3sg-PST-die } \\
\text { 'S/he died' } \\
\text { (N \& H 1993: 366) } \\
\text { (b) } k a-\varnothing \text {-wa-shind-i } \\
\text { 3sg-PST-OM-win-VC } \\
\text { 'S/he won them' } \\
\text { (Whiteley 1953: 35) } \\
\text { (c) } k u-\varnothing-r e r-e \\
\text { 2sg-PST-bring-CV } \\
\text { 'You brought' } \\
\text { (Lambert 1953: 18) }\end{array}$ \\
\hline $\begin{array}{l}\text { /ta-, ca-, nda-/ } \\
\text { 'Future' }\end{array}$ & $\begin{array}{l}\text { (a) } u \text {-ca-fung- } a \\
\text { 2sg-FUT-tie-FV } \\
\text { 'You will tie/ will be tying' } \\
\text { (N \& H 1993: 422) }\end{array}$ & \\
\hline $\begin{array}{l}\text { /nga-, nge/ } \\
\text { 'Conditional' }\end{array}$ & $\begin{array}{l}\text { (a) a-nga-wa-je ... } \\
\text { 3sg-COND-be-how } \\
\text { 'Whatever he is...' } \\
\text { (Lambert 1953: 33) }\end{array}$ & \\
\hline $\begin{array}{l}\text { /ki-, ka-/ } \\
\text { 'Situative' }\end{array}$ & $\begin{array}{l}\text { (a) kavu a-ka-rwanga } \\
\text { 'S/he used to clean grain' } \\
\text { (N \& H 1993: 420) }\end{array}$ & \\
\hline
\end{tabular}


Table 6: Mtang'ata

\begin{tabular}{|c|c|c|}
\hline TA & SET A & SET B \\
\hline $\begin{array}{l}\text { /Ø, a-, na-/ } \\
\text { 'Present' }\end{array}$ & $\begin{array}{l}\text { (a) } a \text { - } \varnothing \text {-aw-a } \\
\text { 3sg-PRST-go-FV } \\
\text { 'She is going' } \\
\text { (Temu 1980: 27) } \\
\text { (b) } a-\varnothing \text {-geuk-a } \\
\text { 3sg-PRST-turn-FV } \\
\text { 'She is turning' } \\
\text { (Temu 1980: 23) } \\
\text { (c) u-na-ko-ka-a } \\
\text { 2sg-PROG-LOC-stay-FV } \\
\text { 'Where you stay' } \\
\text { (Shihabudin \& Mnyampala 1977: 34) }\end{array}$ & \\
\hline $\begin{array}{l}\text { /na-/ } \\
\text { 'Anterior' }\end{array}$ & & $\begin{array}{l}\text { (a) } k u-n a-y a-b u n-u \\
\text { 2sg-ANT-6OM-create-VC } \\
\text { 'You have created them' } \\
\text { (Temu 1980: } 20 \text { ) } \\
\text { (b) ka-na-bak-a} \\
\text { 3sg-ANT-give_out-FV } \\
\text { 'She has given out' } \\
\text { (Temu 1980:23) }\end{array}$ \\
\hline $\begin{array}{l}1 \varnothing \ldots(\mathrm{VC}) / \\
\text { 'Anterior' }\end{array}$ & & $\begin{array}{ll}\text { (a) } & k u-\varnothing \text {-on-o wanihadaa } \\
& \text { (Shihabudin \& Mnyampala 1977: 34) }\end{array}$ \\
\hline $\begin{array}{l}\text { /(me)sha-, ma-/ } \\
\text { 'Completive' }\end{array}$ & & \\
\hline $\begin{array}{l}\text { /li-, e- }, \varnothing \ldots(\mathrm{VC}) / \\
\text { 'Past' }\end{array}$ & 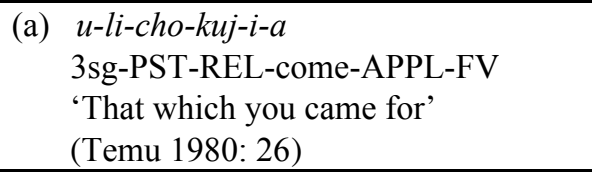 & \\
\hline $\begin{array}{l}\text { /ta-, ca-, nda-/ } \\
\text { 'Future' }\end{array}$ & $\begin{array}{l}\text { (a) a-ta-twig-ish-w-a } \\
\text { 3sg-FUT-pull-CAUS-PASS-FV } \\
\text { 'She will be pulled' } \\
\text { (Temu 1980: 26) }\end{array}$ & \\
\hline $\begin{array}{l}\text { /nga-, nge/ } \\
\text { 'Conditional' }\end{array}$ & $\begin{array}{l}\text { (a) } a-n g e-n i-p-a \\
\text { 3sg-COND-1OM-give-FV } \\
\text { 'S/he could have given me' } \\
\text { (Temu 1980: 17) }\end{array}$ & \\
\hline $\begin{array}{l}\text { /ki-, ka-/ } \\
\text { 'Situative' }\end{array}$ & $\begin{array}{l}\text { (a) } u \text {-ka-pik-a } \\
\text { 2sg-SIT-cook-FV } \\
\text { 'If you cook' } \\
\text { (N \& H 1993: 420) }\end{array}$ & \\
\hline
\end{tabular}


Table 7: Ngome

\begin{tabular}{|c|c|c|}
\hline TA & SET A & SET B \\
\hline $\begin{array}{l}\text { /na(ku)-, a-/ } \\
\text { 'Present' }\end{array}$ & 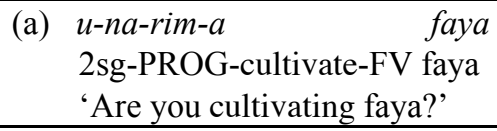 & $\begin{array}{l}\text { (a) } k o-\varnothing \text {-ki-tak-a kiswahili kyangu } \\
\text { 2sg- } \varnothing \text {-7OM-want-FV 7-Swahili my } \\
\text { 'Do you want my Swahili?' }\end{array}$ \\
\hline $\begin{array}{l}1 \varnothing \ldots(\mathrm{VC}) / \\
\text { 'Anterior' }\end{array}$ & & $\begin{array}{l}\text { (a) } k u-\varnothing-m w-o n-o \\
2 \text { sg-ANT-2OM-see-VC } \\
\text { 'Have you seen him?' } \\
\text { (b) } k a-\varnothing-f a n z-a-j e-k o \\
\text { 3sg-ANT-do-FV-how-17-Loc } \\
\text { 'What has s/he done there?' }\end{array}$ \\
\hline $\begin{array}{l}\text { /(me)sha-, ma-/ } \\
\text { 'Completive' }\end{array}$ & $\begin{array}{l}\text { (a) } a \text {-sha-rim- } a \\
\text { 3sg-COMP-cultivate-FV } \\
\text { 'S/he has already cultivated' }\end{array}$ & $\begin{array}{l}\text { (a) ku-sha-rim-a weye? } \\
\text { 2sg-COMP-cultivate you } \\
\text { 'Have you cultivated already?' } \\
\text { (b) ka-sha-gundumk-a? } \\
\text { 3sg-COMP-wake_up-FV } \\
\text { 'Has she woken up already?' }\end{array}$ \\
\hline $\begin{array}{l}\text { /li-, e-, } \varnothing \ldots(\mathrm{VC}) / \\
\text { 'Past' }\end{array}$ & $\begin{array}{l}\text { (a) } a \text {-ri-rim- } a \\
\text { 3sg-PST-cultivate-FV } \\
\text { 'S/he cultivated' }\end{array}$ & $\begin{array}{l}\text { (a) } k u-\varnothing \text {-zarik-a-je? } \\
\text { 2sg-PST-be_born-ST-FV-how } \\
\text { 'How were you born?' } \\
\text { (b) ka- } \varnothing \text {-pit-i pa } \\
\text { 3sg-PST-pass-VC here } \\
\text { 'S/he passed here' }\end{array}$ \\
\hline $\begin{array}{l}\text { /ta-, ca-, nda-/ } \\
\text { 'Future' }\end{array}$ & $\begin{array}{l}\text { (a) a-ta-rim- } a \\
\text { 3sg-PST-cultivate-FV } \\
\text { 'S/he cultivated' }\end{array}$ & \\
\hline $\begin{array}{l}\text { /nga-, nge/ } \\
\text { 'Conditional' }\end{array}$ & $\begin{array}{l}\text { (a) a-nga-rim- } a \\
\text { 3sg-COND-cultivate-FV } \\
\text { 'S/he could have cultivated' }\end{array}$ & \\
\hline $\begin{array}{l}\text { /ki-, ka-/ } \\
\text { 'Situative' }\end{array}$ & $\begin{array}{l}\text { (a) } a-k i-r i m-a \\
3 \text { sg-SIT-cultivate-FV } \\
\text { 'If s/he cultivates' }\end{array}$ & \\
\hline
\end{tabular}

author's e-mail: akipacha@yahoo.co.in 